
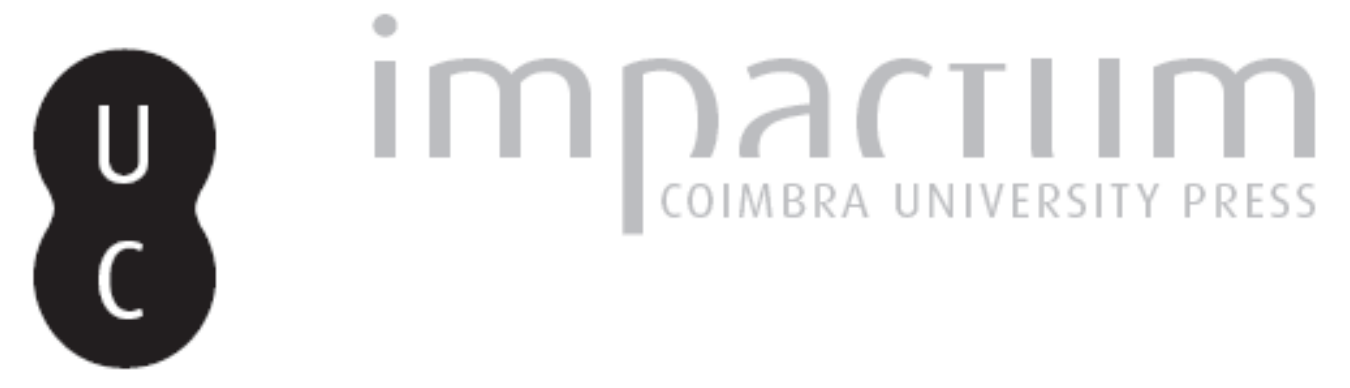

\title{
O cânone bíblico: introdução à História da sua formação
}

Autor(es): Coimbra, Humberto

Publicado por: Centro de História da Universidade de Lisboa

URL persistente:

URI:http://hdl.handle.net/10316.2/33016

DOI:

DOI:http://dx.doi.org/10.14195/0871-9527_22_13

Accessed : $\quad$ 26-Apr-2023 10:08:47

A navegação consulta e descarregamento dos títulos inseridos nas Bibliotecas Digitais UC Digitalis, UC Pombalina e UC Impactum, pressupõem a aceitação plena e sem reservas dos Termos e Condições de Uso destas Bibliotecas Digitais, disponíveis em https://digitalis.uc.pt/pt-pt/termos.

Conforme exposto nos referidos Termos e Condições de Uso, o descarregamento de títulos de acesso restrito requer uma licença válida de autorização devendo o utilizador aceder ao(s) documento(s) a partir de um endereço de IP da instituição detentora da supramencionada licença.

Ao utilizador é apenas permitido o descarregamento para uso pessoal, pelo que o emprego do(s) título(s) descarregado(s) para outro fim, designadamente comercial, carece de autorização do respetivo autor ou editor da obra.

Na medida em que todas as obras da UC Digitalis se encontram protegidas pelo Código do Direito de Autor e Direitos Conexos e demais legislação aplicável, toda a cópia, parcial ou total, deste documento, nos casos em que é legalmente admitida, deverá conter ou fazer-se acompanhar por este aviso.

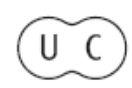



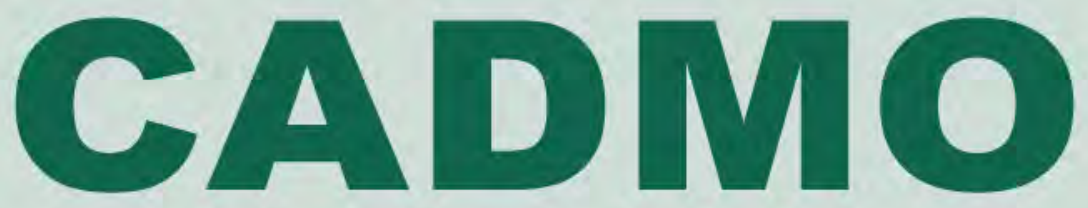

Revista de História Antiga

\author{
Centro de História \\ da Universidade de Lisboa
}

\title{
22
}

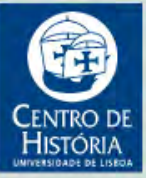

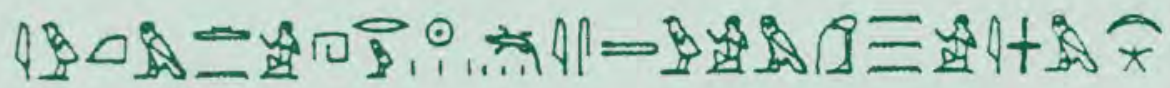

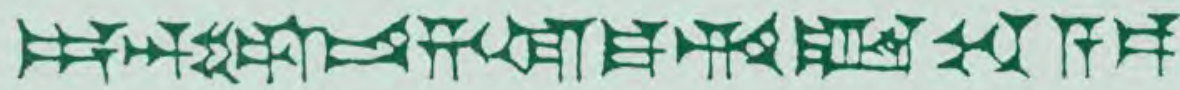
MHNIN AEI $\Delta \mathrm{E} \Theta \mathrm{EA} \Pi \mathrm{\Pi H} \Lambda \mathrm{HIA} \Delta \mathrm{E} \Omega$ 


\title{
O CÂNONE BÍBLICO: INTRODUÇÃO À HISTÓRIA DA SUA FORMAÇÃO
}

\author{
HUMBERTO COIMBRA \\ Universidade de Lisboa \\ humbertocoimbra@gmail.com
}

\section{Resumo}

A história da formação dos cânones da Bíblia expressa em si a complexidade inerente a um tema definido, na sua essência, enquanto resultado da confluência de diferentes sensibilidades e perspectivas, intelectuais e emocionais, espirituais ou académicas. Apenas o facto de falarmos em "cânones» e não no cânone, declara a impossibilidade de fechar o conceito de canonicidade num sentir e compreender universal ao pensamento judaico-cristão. Este processo de construção canónica, que é marcado, sem dúvida alguma, por uma diversidade de estruturas de pensamento convergentes, distingue-se, no entanto, pelos diversos momentos ou etapas de clivagem, que se assumem historiograficamente enquanto ferramentas de construção da identidade judaico-cristã.

Palavras-chave: cânone bíblico; Bíblia; judaísmo; cristianismo

\begin{abstract}
The History of the formation of the Biblical canons expresses in itself the inherent complexity of a subject defined, in its essence, as the result of the confluence of different sensitivities and perspectives, intellectual and emotional, spiritual or academic. Only the fact that we speak in "canons" and not in the canon, declares that it is impossible to close the concept of canonicity into a universal feeling and understanding of the jewish-christian thought. This process of canonical construction, marked, undoubtedly, by
\end{abstract}


a diversity of convergent structures of thought, is distinguished, however, by the several moments or stages of cleavage, which are assumed by the historiography as tools of construction of the jewish-christian identity.

Key-words: Biblical canon; Bible; judaism; christianism

A história do cânone bíblico está repleta de dúvidas, desacordos e flutuações. O Dictionnaire Encyclopédique du Judaïsme afirma que «Sous sa forme actuelle, le canon est le fruit d'un processus historique et littéraire complexe. Mis à part les sources d'époque hellénistique qui font allusion aux dernières phases de cette évolution, les informations émanant des périodes antérieures sont rares et peu concluantes. Par conséquent, toute tentative de reconstitution est sujette à caution.» (Dictionnaire Encyclopédique du Judaïsme 1993: 158) Embora reconheçamos, naturalmente, que a citação acima se refere em particular ao cânone do Antigo Testamento, a verdade é que a necessidade de prudência ou resguardo se impõe, de uma maneira mais alargada, ao estudo do desenvolvimento e da determinação do cânone bíblico no seu todo.

O presente estudo procura apresentar um esboço introdutório à constituição do cânone bíblico, tendo em consideração as etapas principais da sua composição, colocando, no entanto, a ênfase na fase de conclusão ou de encerramento do mesmo. Consideramo-lo um esboço, uma vez que reflecte a simplicidade de uma primeira abordagem do tema, sendo também uma introdução, no sentido de que o objectivo do mesmo é o de sobrevoar as linhas mestras orientadoras que nos permitam obter um panorama geral acerca da história do cânone da Bíblia. Estamos conscientes que uma tal abordagem corre o risco de nos conduzir a uma aproximação demasiado simples e pouco profunda. No entanto, o nosso objectivo é precisamente o de utilizar esta pesquisa como uma ferramenta que nos permita rever questões que sejam pertinentes no intuito de deixarmos em aberto novas vias de reflexão e de investigação.

\section{SIGNIFICADO DO TERMO «CÂNONE»}

A palavra cânone deriva directamente do vocábulo grego kanon. Traduzido literalmente, significa «vara», «cana» ou «cana para medir». No entanto, actualmente, a acepção mais comum deste termo deriva de uma compreensão metafórica que transmite o sentido de «regra» ou «norma». 
Na verdade, o campo semântico da palavra cânone foi variando ao longo do tempo e dos diferentes contextos que o envolviam. Para os filósofos gregos como Epicuro, cânone é a norma ou a regra pela qual é possível distinguir a verdade da mentira. Na Bíblia dos Setenta (Septuaginta ou LXX) - tradução grega do Antigo Testamento (Judite 13:6; Miqueias 7:4; 4 Macabeus 7:21) - e no Novo Testamento (2 Coríntios 10:13,15,16; Gálatas $6: 16)$ o termo é utilizado com vários significados, sendo de assinalar que apenas em Gálatas a referência seja feita no sentido de «regra» segundo a qual os cristãos deveriam andar (cf. Longton, Poswick 1987: 228).

No universo historiográfico judaico-cristão, Orígenes (185-232 a.D.) é o primeiro a utilizar o adjectivo «canónico». Atanásio, no século IV a.D., utiliza pela primeira vez a expressão "Cânone das Santas Escrituras" fazendo referência ao Antigo e Novo Testamentos. A Jewish Encyclopedia, embora reconhecendo a origem «cristã» da utilização do termo cânone enquanto aplicação aos escritos sagrados, afirma no entanto o seguinte: «But although the older Jewish literature has no such designation for the Biblical books, and it is doubtful whether the word was ever included in the rabbinical vocabulary, it is quite certain that the idea expressed by the

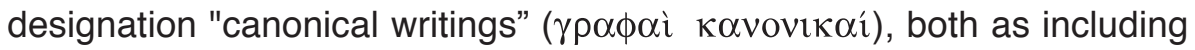
and as excluding certain books, is of Jewish origin." (Jewish Encyclopedia vol. $3: 140)$.

Falar de cânone no contexto actual do cristianismo, imerge-nos na necessidade corporativa ou no imperativo institucional de ortodoxia, enquanto expressão de identidade. Esta perspectiva reguladora impõe-se a vários níveis na vivência do religioso, abrangendo sobretudo a dimensão do comunitário e do cerimonial (por exemplo: «o direito canónico», «a canonização de um santo», etc.), assumindo deste modo um cariz de expressão de autoridade eclesiástica.

O Dictionnaire Encyclopédique de la Bible define cânone como sendo «... une liste close de livres qui sont normatifs pour l'Eglise. Le concept de «norme» est plus important que "liste". Les livres font autorité comme règle de foi et de mœurs. Mais le canon reflète aussi l'identité de la communauté, il révèle comment cette communauté se voyait elle-même. La Bible aide à trouver des réponses aux questions: Qui sommes-nous ? Que devons-nous faire (foi et mœurs)? Le canon répond à un triple besoin: besoin de conserver la révélation, de la préserver de toute corruption, de l'observer dans la foi et la vie.» (Longton, Poswick 1987, op. cit. 228). É precisamente no quadro de estudo da autoridade eclesiástica que o 
conceito de cânone encontra expressão enquanto problema epistemológico. Integrado na esfera da reflexão teológica impulsionada pelas diferentes concepções de «revelação» e de «inspiração divina» (theopneustos) ${ }^{1}$, o conceito de cânone é visto por um lado como estando na origem ou no início de um percurso, por outro, é representado como um resultado ou um produto deste caminho ideológico. É certo que as questões que se levantam estão intrinsecamente relacionadas com as diferentes possibilidades que se apresentam diante do indivíduo na sua aproximação à espiritualidade e de um modo particular na abordagem dos escritos que representam o sagrado ${ }^{2}$. Em suma, a problemática inspiração/autoridade/ /cânone tem definido duas grandes vias paralelas na concepção epistemológica eclesiástica. Na primeira, o cânone é compreendido como o resultado de um binómio combinado: inspiração e autoridade eclesiástica. O livro é o resultado da inspiração divina ${ }^{3}$, consequentemente ratificada pela autoridade da Igreja. Na New Catholic Encyclopedia, na descrição geral dos critérios de canonicidade estabelecidos pela Igreja Católica é afirmado o seguinte: «The problem of the criterion of the Canon remains only partially solved. Catholics hold that the proximate and ultimate criterion is the infallible decision of the church in listing its sacred and canonical books.» (New Catholic Encyclopedia vol. 2 :387). Deste modo, o cânone define-se como um resultado da afirmação da Igreja enquanto autoridade divina. A outra via de compreensão epistemológica parte do pressuposto que «the evidence for canonicity is inherent or intrinsic in Scripture rather than extrinsic in the church.» (Gulley 2003: 322). Deste ponto de vista, a autoridade da Igreja é o resultado da consonância com o cânone escriturístico. A autoridade eclesiástica é o reflexo da autoridade da inspiração reconhecida, e não estabelecida, como sendo canónica. «L'inspiration est une qualité interne du livre; l'acceptation externe du livre dans le canon n'ajoute rien à cette valeur interne, elle est la reconnaissance par le peuple de Dieu de sa valeur normative.» (Longton, Poswick 1987 op. cit. 229).

São na verdade inúmeras as questões e as problemáticas que se levantam quando entramos no universo de estudo do cânone bíblico. Encontramos caminhos de pensamento que nos convidam a indagar acerca do significado, ou poderemos mesmo falar da natureza, no sentido da compreensão da essência do conceito de cânone. Por outro lado, as questões do desenvolvimento histórico no seu enquadramento social e literário colocam-nos diante da realidade de um processo vivo, continuo e em desenvolvimento ${ }^{4}$. Apercebemo-nos que a teologia, enquanto estrutura 
do pensamento religioso, é também o reflexo do olhar e da compreensão dos eventos que a envolvem, constituindo-se um meio de compreensão do ser no espaço físico, cultural e intelectual que o circunscreve.

\section{HISTÓRIA DO CÂNONE DO ANTIGO TESTAMENTO}

Um simples olhar sobre a actualidade ocidental permite-nos compreender a complexidade inerente à constituição do cânone do Antigo Testamento. Para a Igreja Católica, o Antigo Testamento é constituído por 46 livros. No mundo protestante é geralmente aceite uma composição canónica de 39 livros, correspondentes à lista que constitui a chamada Bíblia Hebraica - obra (lista) de referência no judaísmo contemporâneo.

Porque é que existem duas listas diferentes, uma chamada longa (aceite na generalidade pela Igreja Católica) e outra chamada curta (utilizada consensualmente por uma maioria protestante) para o cânone do Antigo Testamento? Quem é que definiu estas duas listas e em que contextos, histórico, social e religioso, foram elas definidas? Será possível conhecer os critérios que levaram a estas escolhas? Procuraremos, nesta segunda parte, abordar as respostas a estas perguntas. Para o fazer, utilizaremos uma estrutura de reflexão dividida em duas partes: 1. O Antigo Testamento no contexto do judaísmo; 2. O Antigo Testamento no contexto do cristianismo.

É pertinente também, neste momento, salientar a diferença que existe entre o estudo da composição ou da formação dos livros do Antigo Testamento e o estudo da formação do cânone do Antigo Testamento. O primeiro universo de estudo aborda o desenvolvimento físico do Antigo Testamento. Questiona, investiga e posiciona-se diante de cada livro, individualmente e consequentemente no seu colectivo, no seu contexto sociocultural imediato. O segundo universo de pesquisa abre a porta para a análise das diferentes atitudes e posturas diante da compreensão da materialização do conceito de «inspiração divina». É nosso objectivo debruçarmo-nos sobre a segunda proposta: o estudo da formação do cânone do Antigo Testamento.

\section{A. O Cânone do Antigo Testamento no judaísmo}

Importa, antes de mais, dizer que a determinação judaica formal do cânone do Antigo Testamento se reporta à era cristã. Tal como teremos a 
oportunidade de aprofundar mais adiante, a ameaça crescente que a "seita dos cristãos» ${ }^{5}$ representava, levou o judaísmo a assumir determinadas decisões acerca do seu cânone. Teremos, de seguida, a oportunidade de abordar este assunto de duas perspectivas complementares: 1) As referências acerca do cânone no Antigo Testamento; 2) $O$ cânone do Antigo Testamento na história do judaísmo.

\section{O cânone no Antigo Testamento}

A Bíblia não faz nenhuma referência directa e clara acerca da existência de um cânone. É possível, no entanto, encontrar passagens que nos reportam à presença de tradições e celebrações que deveriam ser encaradas como meios de transmitir mensagens e ensinos através das várias gerações (Deuteronómio 31:9-13; Êxodo 14:12-51).

Desde cedo se sentiu a necessidade de colocar por escrito os ensinamentos, tais como regulamentos e leis, oráculos proféticos, com o objectivo de os preservar para as gerações futuras. Em 2 Reis 22:8, é dito que "O sumo sacerdote Hilquias disse ao escriba Chafan: "Encontrei no templo do SENHOR o Livro da Lei." ". De acordo com alguns autores, esta referência ao Livro da Lei no tempo de Hilquias (622-621 a. C.) corresponderá provavelmente a uma porção do livro de Deuteronómio (cf. Longton, Poswick 1987, op. cit. 229; New Catholic Encyplopedia, op. cit. 387). Por volta do ano 400 a.C., Esdras lê o «livro da Lei de Moisés» diante da congregação dos «filhos de Israel» (Neemias 8:1 e seguintes). Fala-se nesta passagem do mesmo «código legislativo» a que é feita referência no livro de Esdras, capitulo 7, versículo 14, e que muitos identificam como sendo o Pentateuco. No prólogo do livro de Ben Sira (190 a.C.), o tradutor (130 a.C.) faz referência à «Lei, os profetas e os outros livros..."». O cânone judaico divide-se ainda actualmente em três partes diferentes $^{6}$ : a Lei, os Profetas e os Escritos (Torah, Nevi'im, VeKetuvim). Acreditava-se inicialmente que estas três partes pressupunham um desenvolvimento do processo de canonização marcado por três etapas distintas. De acordo com esta perspectiva, o primeiro Cânone definido teria sido o da Lei, seguido pelo conjunto de livros compreendidos na secção dos Profetas e, por último, os outros Escritos. Actualmente, a compreensão mais comum apresenta uma visão da formação canónica desenvolvida de uma maneira progressiva, mais ou menos conjunta (cf. New Catholic 
Encyclopedia, op. cit. 388, 389). Ainda no livro de Ben Sira, encontramos também algumas referências aos escritos dos profetas, como Isaías (48:22), Jeremias (49:6,7), Ezequiel (49:8) e ainda aos «doze profetas» chamados menores (49:10).

O segundo livro dos Macabeus apresenta Neemias (440 a.C.) como sendo o fundador de uma biblioteca que reuniria «tudo o que dizia respeito aos reis e aos profetas, às obras de David e às cartas dos reis, relativas às ofertas» (2 Macabeus 2:13) Poderíamos nós «ler» nestas palavras uma alusão à segunda e à terceira parte da Bíblia hebraica?

É impensável deixar de mencionar que o estudo do testemunho interno dos livros que compõem o cânone do Antigo Testamento acerca daquelas que seriam as obras de referência no universo literário e religioso judaico, nos imerge em novas questões: Será que todos os livros considerados como sendo inspirados seriam também considerados canónicos? Poderíamos nós pensar na possibilidade de algum livro apreciado como sendo inspirado não ter sido reconhecido como canónico, por ter desaparecido com o tempo? Na verdade, são várias as referências que encontramos na Bíblia, e de uma maneira particular no Antigo Testamento, a livros que tiveram certamente o seu lugar em contextos específicos (cronológico, geográfico ou cultural) e cuja existência não chegou aos nossos dias (Josué 10:13; 1 Reis 14:29; 15:7,31; 16:5; 2 Crónicas 9:29; 12:15; 13:22).

De modo a compreendermos um pouco melhor as diversas dimensões da «escolha» envolvida no processo da constituição do cânone do Antigo Testamento, abordaremos neste momento o desenvolvimento do cânone na história do judaísmo e num terceiro momento analisaremos aqueles que foram apresentados ou identificados como os critérios de estabelecimento do mesmo.

\section{2. $O$ cânone na história do judaísmo}

Tal como já tivemos oportunidade de referir anteriormente, a determinação do cânone do Antigo Testamento, definido enquanto autoridade de fé, reporta-se ao início da era cristã. No entanto, seria errado afirmar que só nesse momento o conceito de canonicidade fora aplicado aos escritos judaicos. Júlio Trebolle Barrera afirma que «No antigo Oriente havia uma ideia de "canonicidade" aplicável a textos enviados dos céus, transmitidos com escrupulosa fidelidade, guardados em lugares sagrados, 
contendo promessas para os que fizessem bom uso deles e maldições para quem os destruísse ou não respeitasse. Em certo sentido este conceito de canonicidade acompanhou desde o princípio o processo de formação do AT; não é correcta a ideia de que o cânone tivesse surgido somente no final do processo (Vasholz).» (Barrera 1999: 179). O mesmo autor faz uma análise paralela entre a história do cânone do Antigo Testamento e a história do Templo de Jerusalém (cf. Barrera 1999: ibidem 179). Baseando-se nos resultados das descobertas arqueológicas mais recentes, apresenta um estudo do desenvolvimento, e de alguma maneira do estabelecimento do cânone assente em quatro períodos distintos:

a. O «primeiro Templo» - o período correspondente à época monárquica a partir do reinado de Salomão: A história do cânone começa com a descoberta do livro de Deuteronómio, na sua versão original, pelos sacerdotes no Templo de Jerusalém no tempo do rei Josias (622/21a.C.). É chamada a nossa atenção para escritos deste período que são citados em livros bíblicos, mas cujo texto se perdeu.

b. O «segundo Templo» - correspondente ao período de restauração pós-exílio até à crise helenista: Aborda a história da formação do Pentateuco e as inconclusivas derivações na constituição das secções dos Profetas e dos Escritos.

c. O «terceiro Templo» - o da época macabaica: De acordo com o autor, «o espaço literário canónico estabelecido na época macabaica continuou sendo praticamente o mesmo nas épocas posteriores, embora ainda na época macabaica e especialmente na época herodiana até aos anos 70 alguns grupos judeus ampliassem ou quisessem ampliar o espaço literário ou cânone dos livros sagrados.» (Barrera 1999 ibidem 192,193).

d. O «quarto Templo» - corresponde ao da época herodiana no período romano: Uma análise das diversas fontes disponíveis deste período permite-nos conhecer as grandes correntes internas ao judaísmo no que diz respeito à formação do cânone das escrituras judaicas. Coloca-se a ênfase nas «discussões» sobre a canonicidade de alguns livros, como o Cântico dos Cânticos, Rute, Lamentações, Ben Sira, Baruc ou o Eclesiastes.

O concílio de Jâmnia (90 a.D.) foi durante muito tempo apontado como um marco cronológico definitivo no processo de fixação do cânone 
judaico. Esta visão não assume o mesmo peso ideológico nos nossos dias. Na verdade, não existe uma data precisa para o momento em que o cânone judaico terá ficado "oficialmente» fechado, impossibilitando a entrada de mais livros. As fontes judaicas (os apócrifos, Fílon de Alexandria ou Flávio Josefo) assim como as fontes cristãs que reflectem a presença judaica (o Novo Testamento, os Padres da Igreja) levam-nos a supor a possibilidade de o cânone ter sido fechado entre o século II a.C. e o fim do século I a.D., provavelmente mantendo as mesmas linhas encontradas no período macabaico. Em Jâmnia houve debates e tomaram-se decisões acerca da constituição do cânone, sobretudo no que diz respeito aos livros pertencentes à secção dos Escritos. Este sínodo é, no entanto, visto actualmente como uma expressão da visão e da autoridade rabínica, que na presença das divergências teológicas do fim do primeiro século, onde se enquadra o desenvolvimento do pensamento cristão, acabou por ratificar a autoridade de um cânone curto ${ }^{7}$.

\section{Critérios de canonicidade}

O estudo dos critérios estabelecidos na assunção de um livro à qualidade de canónico é feito através de um percurso marcado pela diversidade de trilhos ideológicos paralelos da parte dos académicos. Não existe, na verdade, uma concordância geral acerca dos motivos que levaram a comunidade judaica a aceitar os livros do Antigo Testamento como sendo canónicos.

Alguns autores defendem que a natureza legislativa de um livro era tida como critério de reconhecimento canónico (legislativo, regulador). Outros sustentam que o conteúdo inspirado, isto é, promotor de um crescimento e desenvolvimento espiritual e religioso da comunidade, representou um papel fundamental na definição do cânone (New Catholic Encyclopedia op. cit. 389).Uma abordagem analítica do Cânone judaico permite-nos subentender ainda dois critérios básicos presentes na constituição do mesmo: os conceitos de autoridade e antiguidade. Foram reconhecidos como sagrados e consequentemente canónicos os livros considerados de origem mosaica ou profética e cuja génese remontava (supostamente) a uma época anterior à interrupção da cadeia de inspiração profética (no tempo de Artaxerxes, 465-423 a.C.). 
Num comentário aos critérios de canonicidade da Bíblia, Júlio Trebolle Barrera afirma que «tanto no AT como no NT os critérios ideológicos de canonicidade não parecem ter sido tão importantes como o peso da tradição sobre o carácter sacro e canónico de um determinado livro. Se o grupo religioso considerasse necessário incluir um livro que não possuía, com rigor, os critérios estabelecidos, não duvidava em forçar os critérios ideológicos para justificar tais condições. Se a tradição atestava o carácter sagrado de um livro, mas este não cumpria as outras condições exigidas, respeitava-se acima de tudo a tradição recebida.» (Barrera 1999 op.cit. 183). Colocando de parte toda e qualquer intenção de crítica a uma perspectiva epistemológica da importância do cânone na compreensão do religioso, colocamos ainda assim algumas perguntas que nos parecem relevantes, enquanto pistas de reflexão, neste esforço de apreensão da realidade do cânone: Qual o papel da tradição enquanto critério de definição canónica? Poder-se-á supor que a tradição representa de alguma maneira uma expressão de autoridade protocanónica? Por último, qual a origem da autoridade que define os critérios de autenticidade canónica?

\section{B. O cânone do Antigo Testamento no cristianismo}

O primeiro século da nossa era é marcado por dois acontecimentos cruciais na história do judaísmo: a destruição do Templo de Jerusalém, no ano 70 , e a cisão entre o judaísmo e o movimento dos cristãos ${ }^{8}$. Apesar da destruição do Templo, o judaísmo lutou no sentido de definir e impor uma identidade cada vez mais demarcada das influências e ideologias que surgiam à sua volta ou que cresciam no seu interior. O concílio de Jâmnia é uma expressão clara deste esforço. As primeiras comunidades cristãs não se sentiram, no entanto, na obrigação de corresponder às exigências provenientes desse sínodo judaico. Na verdade, a maioria dos primeiros autores cristãos parece não fazer diferença entre os livros protocanónicos e os deuterocanónicos. "An examination of the NT use of the OT shows that the NT writers had the same broad view of the sacred books as the Hellenist and Qumran Jews had of them. The NT writers knew and used a fuller collection that included the so-called deuterocanonical books.» (New Catholic Encyclopedia, op. cit. 390). Alguns autores defendem mesmo que o Novo Testamento cita passagens de alguns livros chamados 
pseudepigráficos (cf. Dorival, Harl. Munnich 1988: 323-325), livros estes, que acabaram por não ser incluídos em nenhum cânone cristão.

O século III a.D. marca um ponto de viragem na atitude da Igreja Cristã diante do cânone do Antigo Testamento. De uma maneira particular, Orígenes assumiu um papel de relevo na delimitação do mesmo. $\mathrm{Na}$ perspectiva de Orígenes, os livros que circulavam no corpus literário do Antigo Testamento dividiam-se em três grupos: os «testamentários», os «apócrifos» e aqueles que não correspondiam a nenhum dos dois anteriores. O primeiro grupo, o dos «testamentários» continha aqueles livros que eram lidos no programa litúrgico das congregações. Estes eram os únicos que poderiam ser utilizados na homilia ou em discussões e comentários espirituais. O segundo grupo de livros, os «apócrifos», não fazia parte das Escrituras e era aconselhada precaução na sua utilização. Quanto à terceira categoria de livros (Ester, Judite, Tobias, Sabedoria), Orígenes aconselhava os mesmos como sendo úteis durante o catecumenato, pela sua simplicidade moral e acessibilidade imediata para o leitor.

No século IV a.D., Atanásio faz uma análise semelhante à de Orígenes, apresentando, no entanto, algumas variações interessantes. $\mathrm{Na}$ sua $39^{a}$ Carta Festiva, Atanásio distingue três categorias de livros: os livros «canónicos»; os livros apócrifos (correspondendo neste caso ao conjunto de livros chamados actualmente de pseudepigráficos); e «os outros livros" - um terceiro grupo onde se inseriam o livro da Sabedoria, Ben Sira, Ester, Judite e Tobias. Comentando o segundo grupo de livros, os «apócrifos», Atanásio define-os como sendo «enganadores» e «condenáveis». A terceira categoria de livros, tal como acontecia com Orígenes, é também recomendada para o ensino daqueles que se iniciam na fé. É de enfatizar a evolução que se percebe claramente na atitude face aos "apócrifos". Orígenes sugeria "precaução na sua utilização", enquanto na abordagem de Atanásio estes eram vistos como "enganadores" e "condenáveis". "Ainsi, tout se passe comme si, du ler au IVe siècle, l'Église grecque manifestait une tendance croissante à limiter son AT aux livres du canon hébreu. L'origine de cette évolution est peut-être à chercher dans les nécessités de la polémique anti-juive: au II siècle, dans sa controverse avec Tryphon, Justin cite uniquement les livres admis par les Juifs dans leur canon." (New Catholic Encyclopedia, ibidem 324).

A controvérsia e as divergências teológicas acerca do Cânone, enfatizando perspectivas diferentes na compreensão do conceito de revelação, reflectiram-se, ao longo da história do Cristianismo, na flutuação entre 
uma lista curta (cânone judaico) e uma lista longa (cânone alexandrino), arrastando-se até 1546 a.D., onde no concílio de Trento a decisão tomada privilegiou o cânone alexandrino que inclui os livros deuterocanónicos. Esta mesma decisão acabaria por ser ratificada, no ano 1870 a.D., no concílio Vaticano I. Seria, no entanto, errado afirmar que a questão ficara definitivamente encerrada no mundo cristão. Com o alvorecer da Reforma protestante, a discussão em volta do cânone, dos livros protocanónicos e deuterocanónicos, manteve-se acesa.

De uma maneira geral o mundo protestante acabou por rejeitar os livros deuterocanónicos na lista dos livros considerados inspirados, optando antes pelo cânone judaico. No entanto, uma breve análise das diversas traduções da Bíblia, assim como das diferentes confissões de fé, consideradas de referência histórica pelo protestantismo ${ }^{9}$, levam-nos a compreender que a atitude do mundo protestante face ao cânone tem vindo a ser objecto de evolução e de discussão. Embora alguns autores defendam que na actualidade a opção pelo cânone judaico esteja a ser seriamente questionada nos círculos académicos protestantes (cf. Longton, Poswick 1987 op. cit. 230), em termos efectivos, a posição da maioria do mundo protestante permanece essencialmente a mesma.

As grandes perguntas que se levantam ao abordarmos a história da constituição do cânone no contexto da génese e do desenvolvimento das teologias emergentes no processo global da Reforma protestante, colocam-nos diante da enorme complexidade de discernir as influências e as motivações. Em resumo, poderemos nós determinar claramente quais os vínculos existentes entre o conceito de Sola Scriptura, enquanto negação da Tradição fundamentada num conceito de autoridade eclesiástica intrínseca, e a opção protestante pelo cânone judaico como corpus literário do seu Antigo Testamento?

\section{HISTÓRIA DO CÂNONE DO NOVO TESTAMENTO}

\section{A. Panorama geral}

«À l'époque où les 27 écrits ont été composés, ils n'étaient pas encore "Ecriture sainte". Comme nous l'avons dit, l'Ecriture sainte, pour les auteurs du Nouveau Testament, était l'Ancien Testament.» (Cullmann 
1982 117). Para os primeiros cristãos, tal como acontece ainda para os Judeus nos nossos dias, não existia o conceito de Antigo Testamento.

Eles tinham simplesmente as Escrituras, uma vez que não havia ainda um texto definido ou organizado do Novo Testamento. Historiograficamente, Melito de Sardes (170-180 a.D.) é o primeiro a utilizar a expressão «Antigo Testamento", enquanto, só por volta de 200 a.D. Tertuliano utiliza pela primeira vez a locução «Novo Testamento».

Por volta dos anos 50 a.D. começou-se a colocar por escrito a tradição oral acerca dos ensinos de Jesus. Na medida em que estes escritos iam aumentando, começou a fazer-se sentir a necessidade de uma triagem. Um dos factores compreendidos como requisito de autoridade dos escritos do Novo Testamento foi o da apostolicidade. O aspecto valorizado não foi tanto o da «santificação» apostólica, mas sim o da proximidade temporal e circunstancial para com a tradição transmitida. Outros elementos tidos em conta eram os da apostolicidade da igreja local que tinha recebido esses escritos e a ortodoxia dos mesmos.

Clemente de Roma (96 a.D.), na sua Primeira Carta, deixa subentender os primórdios do cânone cristão, ao afirmar que os ensinamentos de Jesus e dos apóstolos, citados de memória ou lidos a partir de textos escritos são comparáveis em valor às antigas Escrituras. Na Epístola de Barnabé (entre 70-100 a.D.) e na Didaquê (século I a.D.) apercebemo-nos em determinadas passagens que os seus autores estavam familiarizados com alguns dos relatos dos evangelhos e das mensagens das epístolas. Inácio de Antioquia (35-107 a.D.) considera normativos, não apenas os ensinamentos de Jesus, mas também as pregações dos profetas e os ensinos dos apóstolos.

Por volta do ano 144 a.D., a controvérsia levantada por Marcião ao rejeitar todos os escritos do Antigo Testamento, assim como por aceitar um só Evangelho (uma forma abreviada do Evangelho de Lucas), e reconhecer autoridade de fé unicamente às Epístolas de Paulo, foi um impulsionador importante no processo de definição do cânone cristão. De entre os vários movimentos de reacção suscitados face ao posicionamento de Marcião, enfatizamos a orientação de Ireneu de Lião, que sem falar ainda de um cânone do Novo Testamento, atribui o título de Escritura, reservada até então unicamente aos escritos do Antigo Testamento, a escritos cristãos, considerando-os inspirados por Deus e normativos.

Quando abordamos a história da definição do cânone do Novo Testamento é fundamental referir que a história da Igreja cristã, onde a 
anterior se insere, não se define uniformemente de uma perspectiva eclesiástica universal. As flutuações ideológicas fomentadas pela diversidade que desde cedo constituiu a identidade do cristianismo, colocam-nos diante de uma linha historiográfica com derivações paralelas, por vezes divergentes, por vezes complementares. «In the East the Canon was fluid and extended to many books not now recognized as Canonical. Justin's euvagenlion, for instance, was any proclaiming of the good news, and many writings could have fulfilled this definition. In the West the Canon was more juridical and normative, tending to exclude rather than include sacred books. Only in the $5^{\text {th }}$ century did the church come to a universal stabilization of the Canon, and not until the Council of Trent did the Canon receive its dogmatic definition.» (New Catholic Encyclopedia, op. cit. 324). Uma vez mais relembramos que seria um erro pretender que a decisão de um concílio eclesiástico colocara uma pedra no debate acerca do cânone. A Reforma protestante e o esforço das diversas sociedades bíblicas no sentido de traduzir a Bíblia, continuaram a abrir a porta da reflexão sobre a inspiração e a validade dos critérios de canonicidade.

\section{B. Cânones do Novo Testamento}

A história do cânone do Novo Testamento poderia, na verdade, ser chamada de «história dos cânones» do Novo Testamento. Os diferentes cânones que foram surgindo ao longo da existência do cristianismo, nasceram como uma expressão das diferentes sensibilidades da Igreja no seu pluralismo ideológico, cultural e geográfico.

Tal como tivemos a oportunidade de referir anteriormente, a lista de livros considerados inspirados por Marcião apresenta-se como um exemplo da importância de considerar a intervenção, directa ou indirecta, das diferentes fontes de influência que circundaram as propostas de listas de escritos considerados sagrados. No caso particular de Marcião, cuja visão teológica era profundamente marcada pela concepção da existência de dois deuses em confronto, o deus dos Judeus e o deus dos Cristãos, apercebemo-nos com facilidade que a sua lista de livros inspirados, considerada por vezes como sendo a primeira proposição de um "cânone fechado", define-se na sua essência como uma enunciação e uma consequência do seu pensamento teológico. Poder-se-á desligar o pensamento teológico do contexto sociocultural que o rodeia? Certa- 
mente não. Daí concluirmos que o interesse do estudo das diferentes listas ou cânones provenientes das mais diversas realidades ao longo da história, prende-se, em grande medida, à oportunidade de compreender perspectivas, mentalidades e consciências.

Por outro lado, o estudo comparativo dos diferentes cânones do Novo Testamento dá-nos uma visão da evolução da atitude que a Igreja foi tomando diante dos diferentes livros e, mesmo até, diante das diferentes colecções de livros. Num artigo acerca do cânone do Novo Testamento, editado no The Blackwell Companion to the New Testament, Leslie Baynes afirma o seguinte: «The letters of Paul are the earliest Christian documents that have survived, and they may also be the earliest Christian documents gathered and promulgated as a group. "The canon is in the main a collection of collections," writes Harry Gamble (2002: 275), and we have already seen that by the end of the second century the four gospels were appropriated as a group.» (Aune 2010: 95). Aproximadamente por volta do ano 180 a.D., Ireneu de Lião defende, de uma perspectiva poética ou mesmo homilética, o valor espiritual intrínseco da escolha da colecção dos quatro evangelhos (Mateus, Marcos, Lucas e João). Orígenes defendia, de modo semelhante, que os quatro evangelhos se demarcavam, de entre as várias dezenas de relatos acerca da vida de Jesus, como sendo os únicos cujo valor era indiscutível na igreja de Deus abaixo dos Céus (cf. Aune 2010 ibidem 94). As colecções das cartas de Paulo também se foram multiplicando desde cedo na história da Igreja. "Collections of Paul's letters may have appeared long before Marcion, perhaps even during Paul's lifetime. David Trobisch argues that "Paul himself collected and gathered some of his own letters" (Trobisch 1994: vii), specifically 1 and 2 Corinthians, Romans, and Galatians, in order to articulate his own agenda regarding the Gentiles in opposition to the apostolic "pillars" of the Jerusalem church.» (Aune 2010 ibidem 96). O estudo dos diversos cânones do Novo Testamento permite-nos ainda confirmar que apesar de haver, de uma maneira geral, convergência nas colecções assumidas como autoridade escriturística, existem, por vezes, dentro das mesmas, divergências quanto ao valor individual de determinados livros (como é o caso da Epístola aos Hebreus, Tiago ou o Apocalipse).

A análise das diferentes listas canónicas permite-nos também inferir os três principais critérios de canonicidade que acompanharam o complexo processo de determinação do cânone do Novo Testamento. O primeiro, e possivelmente o mais antigo critério tido em conta pela 
Igreja Cristã, refere-se ao autor do livro. Quem é que escreveu a obra em questão? Com que autoridade é que o autor transmitiu as informações ou as tradições ali apresentadas? Seria o autor um apóstolo, alguém que tenha testemunhado os eventos transmitidos? Deste modo, o critério da apostolicidade (o autor é reconhecidamente um apóstolo ou alguém próximo a um apóstolo) foi-se revelando como uma marca de autoridade, não tanto pelo valor espiritual intrínseco do autor, mas sobretudo pela fiabilidade do seu testemunho, tendo em consideração a sua proximidade com as tradições transmitidas. O segundo critério é o da ortodoxia. Mesmo quando um determinado livro pretendesse ter autoridade apostólica, se o seu conteúdo não se integrasse na linha ideológica representada pela «regra de fé» existente na Igreja, concluía-se que certamente não teria sido escrito pelo seu pretenso autor. O terceiro e último critério de canonicidade, analisado neste trabalho, é o critério da utilização eclesiástica. Este critério baseava-se na importância e no espaço que um determinado livro ocupava nos serviços litúrgicos das diferentes congregações. Isto é, a utilização de um determinado livro apresenta-se como uma preferência local de uma ou de outra congregação ou, pelo contrário, a sua utilização é mais abrangente e estendida na geografia eclesiástica, sendo deste modo reconhecido o seu valor na edificação litúrgica da Igreja?

Tal como tivemos a possibilidade de verificar com o estudo da história do cânone do Antigo Testamento, também o processo de definição do cânone do Novo Testamento se descreve pela sua complexidade. No entanto, de uma maneira particular, a riqueza historiográfica que envolve o desenvolvimento do cânone do Novo Testamento, coloca, diante do investigador, um universo vasto e rico de possibilidades de estudo e aprofundamento, permitindo descobrir a cada passo novos caminhos e novas oportunidades de questionamento e reflexão.

\section{Conclusão}

A fixação de um cânone bíblico é o resultado de um processo histórico complexo, imbuído e expressivo de leituras e interpretações marcadas pelos variados contextos sociológico, religioso e teológico que determinaram as diversas etapas do desenvolvimento do pensamento judaico-cristão. Apesar e para além das lacunas de matéria historiográfica, existentes em grande medida pela dificuldade de estudo ou mesmo pela impossibilidade 
de acesso às fontes primárias, é fundamental, ao processo de investigação, determinar o tecido ideológico envolvente às diferentes etapas basilares da formação do conceito regulamentar de um cânone.

Na verdade, seria ingénuo, ou diremos mesmo errado da nossa parte, falar, neste momento, do cânone bíblico, como se o conceito representasse uma compreensão una e consensual. Com efeito, para uma maior exactidão, vemo-nos obrigados a falar dos cânones da Bíblia, quer por uma questão de rigor para com a realidade contemporânea, quer mesmo pela pluralidade de perspectivas e posicionamentos ideológicos com os quais o tema do cânone bíblico tem sido brindado com o decorrer da história.

Se por um lado a discussão parece encerrada ou pelo menos adormecida, na perspectiva daquele que crê e que alicerça a sua crença no «sólido fundamento» da Palavra «divinamente inspirada», por outro lado o pensamento académico, ou melhor, o pensamento crítico continua na actualidade a levantar o véu da irresolução em relação a variadíssimos contornos do panorama geral deste quadro milenar. Um dos desafios encontrados no estudo do processo de determinação do cânone bíblico prende-se à dificuldade de especificar os limites e os lugares comuns entre a história e a teologia. Se por um lado, os testemunhos historiográficos nos servem enquanto marcos de compreensão da evolução das sensibilidades e do desenvolvimento de um conceito, por outro lado, o sentido epistemológico do mesmo, é um reflexo das estruturas teológicas do pensamento. A consciência de tal complexidade conduz-nos naturalmente a uma atitude que poderíamos designar por «humildade metodológica», valorizando a necessidade de definir à partida, de uma maneira concreta, os limites e os objectivos a atingir no decurso da investigação.

De entre as grandes linhas de reflexão que sobressaem no estudo do tema do cânone da Bíblia, gostaríamos, em conclusão, de deixar dois pensamentos que permanecem diante do investigador como colunas basilares de uma imponente estrutura: Como é que o conceito de cânone se desenvolveu ideologicamente, de modo a definir uma lista ou um conjunto fechado, perfeito? De que modo a compreensão do cânone bíblico enquanto lista completa e fechada, influenciou o desenvolvimento das concepções teológicas contemporâneas de revelação e inspiração? Perguntas com estas, justificam a pertinência da «humildade metodológica» na abordagem de um tema tão vasto, relembrando-nos que cada novo passo desvenda diante de nós novas oportunidades de questionamento e novas possibilidades de investigação. 


\section{Notas}

(1) Em 2 Timóteo 3:16 a Bíblia afirma que «De facto, toda a Escritura é inspirada por Deus...» (pasa graphe theopneustos). Para ver uma abordagem possível, acerca das diferentes problemáticas relacionadas com a questão da inspiração divina, ver Gulley (2003), SystematicTheology - Prolegomena, Michigan: Andrews University Press.

(2) Ver especialmente o artigo «Sobre as Categorias de Leitura Específicas da Bíblia» escrito pelo Professor Doutor José Augusto Ramos na obra Percursos do Oriente Antigo (editado em 2004, pelo Instituto Oriental da Faculdade de Letras da Universidade de Lisboa, em homenagem ao Professor Doutor José Nunes Carreira na sua jubilação académica).

(3) «It has been the constant belief of the people of God both before and after the time of Christ that their Sacred Scriptures have been divinely inspired.» In New Catholic Encyclopedia, vol. 2, Washington: The Catholic University of America, 1967, pp. 381-382.

(4) Encontramos uma análise interessante acerca do processo histórico de formação do cânone bíblico nas palavras de Júlio Trebolle Barrera: «Se é importante a decisão final de uma autoridade religiosa sobre a lista de livros oficialmente reconhecidos, mais importante é o processo histórico pelo qual os livros vão adquirindo carácter sagrado e reconhecimento canónico.» (Barrera (21999), A Bíblia Judaica e a Bíblia Cristã - Introdução à história da Bíblia, p. 179.)

(5) De acordo com o Novo Testamento, o cristianismo era visto nas suas origens como uma ramificação do judaísmo (Actos 9:2; 24:5,14; 28:22). O termo "seita» (hairesis) é utilizado no livro de Actos dos Apóstolos para se referir a outras facções do judaísmo, como os saduceus ou os fariseus (Actos 5:17; Actos 15:5).

(6) Para uma abordagem sintética do conteúdo de cada umas destas três partes, ver o artigo "Bíblia e Cristianismo" de Jean Baubérot na obra dirigida por J. Delumeau (1997), As Grandes Religiões do Mundo, pp. 67-68.

(7) Esta conclusão não aborda a problemática levantada pelo cânone da LXX ou pelas divergências «canónicas» dos escritos essénios, tal como nos são propostos pelos manuscritos de Qumran.

(8) O livro de Actos dos Apóstolos, no capítulo 11, no versículo 26, relata, de acordo com a perspectiva bíblica, o momento em que o título «cristãos» foi atribuído pela primeira vez aos seguidores de Jesus, enquanto messias.

(9) Referimo-nos por exemplo às traduções da Bíblia de Wyclif (1382), Lutero (1534), Coverdale (1535) ou a Confissões de Fé tais com a de Westminter.

\section{Bibliografia}

\section{Instrumentos de trabalho}

Bíblia Sagrada, $4^{a}$ edição, Lisboa: Difusora Bíblica, 2003.

Dictionnaire Encyclopédique du Judaïsme, Paris: Cerf, 1993.

LONGTON J., POSWICK R.-F., coords (1987), Dictionnaire Encyclopédique de la Bible, Turnhout: Brepols.

New Catholic Encyclopedia, Vol. 2, Washington: The Catholic University of America, 1967.

Novo Testamento Interlinear, Grego-Português, Barueri (SP), Sociedade Bíblica do Brasil, 2004. 


\section{Monografias}

ARCHER G.L. (1991), Introduction à L'Ancien Testament, Saint-Légier: Editions Emmaüs.

AUNE D.E. ed. (2010), The Blackwell Companion to the New Testament, Blackwell Publishing Ltd.

BARRERA J.T. (21999), A Bíblia Judaica e a Bíblia Cristã - Introdução à história da Bíblia, Petropolis: Editora Vozes.

CULLMANN O. ( $\left.{ }^{4} 1982\right)$, Le Nouveau Testament, Paris: Presses Universitaires de France.

DELUMEAU J. (1997), As Grandes Religiões do Mundo, Lisboa: Editorial Presença.

DORIVAL G., HARL M., MUNNICH O. (1988), La Bible Grec Des Septante - Du judaïsme hellénistique au christianisme ancien, Paris: Éditions du Cerf, Éditions du C.N.R.S.

GULLEY Norman R. (2003), Systematic Theology - Prolegomena, Michigan: Andrews University Press.

RAMOS J.A., ARAÚJO L.M., RAMOS DOS SANTOS A., coords (2004), Percursos do Oriente Antigo - Homenagem a José Nunes Carreira, Lisboa: Instituto Oriental da Faculdade de Letras da Universidade de Lisboa.

\section{Fontes on-line}

Jewish Encyclopedia, in http://www.jewishencyclopedia.com/. 